\title{
Exploring the Effects of Adult and Community Education and Training on Economic Development of Women, in South Africa
}

\author{
Sampson Tawiah (PhD Candidate) \\ University of South Africa Pretoria, South Africa
}

doi: 10.19044/esj.2017.v13n22p94 URL:http://dx.doi.org/10.19044/esj.2017.v13n22p94

\begin{abstract}
In South Africa, Adult and Community Education and Training (ACET) is established to cater for the educationally disadvantaged individuals, especially rural women, hence, ACET programmes are running in the country nationally. One of the aims of ACET is to open economic opportunities for women; however, the majority of rural women are still performing poorly economically. This empirical study aimed to explore the effect of ACET on the economic development of women in the Lusikisiki district of South Africa. A qualitative approach in the form of a case study design was used for the study to help the researcher relate to the real life circumstances of the women. Purposive sampling was used to select 35 participants from a population of 115 . The participants were selected because they had wealth of information and could explain better the phenomenon under study. Data collection instruments used were face to face individual interviews which were audio recorded with the consent of participants. The major findings of the investigation include the following: inadequate learning resources available to women; inadequate skills development programmes provided and skeptical perception of the economic benefit of ACET to women. The study suggested that the programmes of ACET should be restructured and skills driven to meet the needs of women, especially in rural communities.
\end{abstract}

Keywords: Women Development; Skills Programmes; Education; Economic Development; South Africa

\section{Introduction}

Most people in South Africa, especially women, were disadvantaged educationally during the apartheid era. The devastating effects of the apartheid government prior to 1994 affected the educational prospects of most South Africans, especially rural women. In view of this the post- 
apartheid government, in a position of full control of the country, attempted to correct the ills of apartheid. They instituted Adult and Community Education and Training (ACET) (ANC, 1994) as a programme to empower the majority of the illiterate populace, particularly rural women. The aim of ACET was to provide skills training, increase employment and economically develop the disadvantaged members of society which include women fold. However, this researcher observed that the anticipated developmental effect of ACET was not successful. This notion is confirmed by Baatjes (2008) in a study he conducted that the programmes offered at ACET centres failed to meet the needs of the individuals it was intended for. As a result, the women, therefore, lack adequate or relevant skills needed for employment. Furthermore, they failed to engage in economic activities to improve their living conditions. It is against this backlog of information that motivated the researcher to investigate the effect of ACET on the economic development of women in the Lusikisiki district of South Africa.

\section{Background}

The failure of women, especially rural women, to perform well in economic activities is of international concern. This is because women lack skills necessary for gainful employment and to participate in the economy by gaining employment to improve their living conditions. This problem emanates from the fact that majority of women in the world, South Africa inclusive are illiterates (Adelore \& Olomukoro, 2015; Medel-Añonuevo, 2013). This suggests that literacy programmes and skills training should be directed towards the economic development of women (UIL, 2013). One of such interventions is 'United Nations Educational, Scientific and Cultural Organization (UNESCO)'s Literacy Initiative for Empowerment (LIFE)' (Kairies, 2013, p.8). This literacy intervention targeted women, however, LIFE'S initiative only focused on women literacy. It did not provide women with relevant skills and training for economic development. The author of this study, therefore, seeks to contribute to this knowledge gap by exploring the effect of ACET on the economic development of women in the study area.

Notwithstanding, there has been some economic benefit of literacy programmes provided to women. Tang (2005) conducted a study and mentioned that UNESCO's LIFE initiative helped develop women economically through core literacy work linked to life skills, income generation and sustainable development. Robinson-Pant (2004) also in a study conducted indicated that statistics were given to measure the economic benefit of literacy programmes to women. For instance, in Pakistan, women with a high level of literacy earned $95 \%$ more than women with no literacy skills (UNESCO-INRULED, 2012). Earning better wage, therefore, mean 
better economic development for the women. Whether or not this literacy programme catered for the majority of women, deserves to be investigated to ascertain its economic impact in the lives of the women concern. This is because as observed by the researcher, the majority of women are still performing poorly economically (Mayer et al., 2011) and the situation is condensed mostly in the rural communities of South Africa.

One most important way to get women out of the problem of a lack of economic development is through education with particular reference to Adult and Community Education and Training (ACET). It is agreed by scholars that although ACET cannot guarantee economic growth, it is fundamental to the economic development of women. Igbuzor (2006) stressed that education is the best gadget for development. In other words, education is seen as the most significant instrument for changing the economic difficulties of women in the society and rural communities. The author, therefore, maintained that education should be provided to all especially rural women. The declaration in Jomtein Thailand in 1990, and reaffirmed in Dakar Senegal in 2000, indicated that educational opportunities should be extended to all without exception by 2015 (FGN, 2004). When all have access to equal education, for the purpose of this study Adult and Community Education and Training, then sustainable economic development can be achieved in the lives of the women.

Sustainable economic development requires changes that are evident in the lives of people, particularly women. The provision of ACET plays a crucial role in bringing about this change. However, the anticipated developmental effect of ACET is not visible in the lives of the women concern. Women are unemployed and living in poverty. The Global Report on Adult Learning and Education revealed that adult education is a powerful tool for eradicating poverty and acquiring skills for sustainable economic development (UIL, 2009) however, it noted that the institution of adult education was neglected in many countries. The institution gets very little resources for its programmes. For example, the Asia South Pacific Bureau of Adult Education (ASPBAE, 2012) found that less than 1\% of national education budgets were spent on adult education and literacy. This neglect has contributed to a lack of skills and economic development for many youths including women.

In South Africa, the situation is no different. This has resulted in a condition where many youths, particularly women, are faced with the problem of poverty and unemployment. This has affected their participation in economic activities for better living conditions. Despite the fact that many young people have access to education as compared to the generation before them, they have been unable to access the economy to benefit them. Over $60 \%$ of South Africans under the age of 25 are unemployed and many have 
lost hope in their search for jobs (Mayer et al., 2011). This shows that the emergence of young South Africans youths today will also face similar problems. These include finding jobs to improve economic status and living conditions and engage in economic activities. It is, therefore, suggested by the researcher that these youths which include women can be given hope through the development of educational policies. Again, appropriate skills training should be provided for youths and adults, especially women (HSRC, 2002).

On the contrary, the researcher continued to stress that this hope of the women is far from realisation if something drastic is not done. For example, according to May and Govender (1998), the labour market must do more in playing a successful role to alleviate poverty. Furthermore, the adult education system should deliver appropriate skills needed in the labour market (Leibbrandt et al., 2010). Without these measures, in place, women will continue to be marginalised, unemployed and live in poverty. The South African National Youth Policy 2009-2014 confirmed this and made a very critical observation about the socio-economic circumstances of unemployed women. It stated that:

"The young women and men can be described as those who have dropped out of school prematurely and are unskilled. They are mostly unemployed since they do not have the starting qualifications. They have no adult supervision; have poor levels of general welfare and experience increased levels of stress. Since some of these youth lack basic literacy and numeracy and are mostly unskilled, they remain marginalised from the economy as they lack the capabilities to access economic opportunities. At present, there are limited programmes aimed at addressing the needs of these youth," (Presidency, 2009, p.10).

It is beyond doubt that the South African education and training institutions have a mountain of responsibility to develop appropriate skills and capacities for the current youth, especially women population. In trying to solve the problem women are faced with the government has put into place interventions currently to facilitate young people's access to the labour market. For example, Formal education; Vocational training; Public employment and deployment programmes; Entrepreneurship interventions and Job placement programmes and for the purpose of this study Adult and Community Education and Training. These are interventions meant to help solve the problems of women (Mayer et al., 2011). However, these programmes have not fully benefited the majority of women. This is in fact confirmed by Mayer et al $(2011$, p.7) that majority of women still lack skills, unemployed, poor and lack economic development. 
Nevertheless, according to the Millennium Development Goal (MDG) Country report (2013), statistics indicated that as far as poverty is concerned, the country has made a lot of progress. However, the researcher observed that the levels of poverty among vulnerable groups such as children and women, which is higher than the poverty levels for the general population, still remain a major challenge in the district under study. While there has been a large increase in the number of people employed, this has been run down by the greater number of people looking for work. The reasons for this include population growth, increasing urbanisation and increasing numbers of women looking for work, due to advances in gender equality (Stats SA, 2012). Considerable progress has been made in ensuring greater equality in employment in terms of race and gender, yet, there are still challenges that do exist. In 1994 for example, only 34\% of working-age Africans and only $26 \%$ of African women were employed. By 2013, employment of Africans has risen to 43\%. Also, about 38\% of African women were involved in wage employment to improve their economic status (Stats SA, 2012). The researcher, however, concluded that despite these increases in employment, there is still a lot more that is needed to be done. This is because there are still many women who are living in poverty, unemployed, unskilled and lack economic development.

\section{Theoretical Framework}

The study is anchored on the Human Capital Theory. This theory explains that investment in education increases one's efficiency and access in the labour market. Furthermore, it enhances increases in better wage employment (Becker, 1964). The increase in access to the labour market and wage increase in employment will mean better economic development for women. This is actually supported by Tachibanaki (1994) that higher educational opportunities had led to higher occupational achievement. In other words, increased responsibility at work and better occupational achievement had led to higher earnings. This shows that investment in the education of women will give them better job opportunities and better wage employment. This, in turn, will help women improve their economic lives as well as their families. The Human Capital Theory further sustained that education should not be viewed simply as consumption, but rather, as a productive investment. The product of which must be visible in the lives of the women involved in Adult and Community Education and Training (ACET) programmes.

According to Bryant (1990) and (cited in Reynolds \& Weagley, 2003), Human Capital is defined as an individual's knowledge, skills, and productive abilities. There have been many disagreements on the issue of Human Capital Theory, however, studies were done (for example, Lockhead, 
Jamison, \& Lau, 1980; Psacharopoulos, 1985) which revealed that investment in education has led to increased productivity, an opportunity to secure higher paying jobs, and have brought about economic growth. The Human Capital Theory, therefore, focused on skills acquisition through education as a means of empowering women for economic gains. Also, this will lead to self-development and involvement in the economic activities of the society. The theory also focused on capacity building premised on the perception that there is always an economic return on investment in education. In this case, there is skill or capacity building for individual learners. Such an investment seemed to provide returns in the form of individual skills acquisition, benefits of literacy programmes and its application for economic success and accomplishment (Blaug, 1970; 1976; Karabel \& Halseu, 1977; cited in Akintayo \& Oghenekohwo, 2004). Indeed, women are to be provided with relevant skills to improve their economic lives.

The Human Capital Theory is relevant to this study as it lays importance on the investment of people especially women involved in ACET programmes through educational activities for skills training. This will ultimately lead to capacity building in economic development and eventually the empowerment of women through skills training for better living conditions. Olomukoro (2012) emphasised that without investment in Human Capital, skills will not be acquired and there cannot be selfdevelopment and improved socio-economic status. There is, therefore, a need to consciously empower women with skills and knowledge through ACET programmes. Arguably, it is through the acquisition of formal knowledge and skills that women are able to take control of their lives, economically develop themselves and take full advantage of the economy.

\section{Research Problem}

The majority of women still lack skills, unemployed and live in poverty. They are economically derailed despite their involvement in Adult and Community Education and Training (ACET) programmes. The aim of the study, therefore, is to explore the effect of ACET on the economic development of women in Lusikisiki, South Africa.

In view of this, three research questions have been formulated to guide the study. These questions include the following:

i.In what ways have ACET programmes benefited women economically?

ii. Which skills development programmes are provided to women?

iii.Are there adequate educational resources available to women in lusikisiki? 


\section{Research Design and Methodology \\ Data collection}

Data collection instrument used for the study were face to face individual interviews. Interviews were semi-structured. Semi-structured interviews were presented as a guide to all participants in a systematic manner. The researcher also asked probing questions for better understanding that can enhance effective response (Berg, 2004). The interviews conducted lasted over a period of 10 days, and each interview lasted 45 minutes to one hour. The interviews were audio recorded with the permission from the participants. This helped the researcher to refer to the recorded interview to transcribe relevant information. 35 participants were purposively sampled out of a population of 115 as they had rich information and could explain better the phenomenon under study. These selection criteria allowed participants to provide dependable and reliable information for the research study.

\section{Ethical Considerations}

Ethical considerations, according to Creswell and Clark (2011) researchers are obliged to respect the rights, needs, values and desires of the research participants. As suggested by Welman et al (2005) the researcher put into practice all research ethical protocols which included: permission, confidentiality, voluntary participation, respect for participants and appropriate referral. These are briefly discussed below:

Permission: Permission was sought from the Department of Education and the Department of Adult Basic Education and Training in the Lusikisiki district to conduct the research. A copy of these permission letters was given to principals and facilitators of ACET centres. The research participants were informed when the research study would formally end and made them aware of how much their valuable time would be consumed (Chaska, 2008). In fact, Tilley, Killins and Oosten (2005) argue that researchers who recruit participants are required to obtain permission from the authorities concerned.

Confidentiality: All effort was made by the researcher to treat information that an individual participant might have given with confidentiality. Information was given in a relationship of trust and with the expectation that it will not be divulged to others without permission in ways that are inconsistent with the understanding of the original disclosure (University of California, 2014).

Voluntary participation: The researcher met with the participants to inform them about the purpose of the research and the need for voluntary participation. The researcher ensured that participants based their participation on the full understanding of the possible risks involved. 
Respect for participants: The researcher respected the participants' views and integrity and would not share confidential information without the participant(s) consent or ethical justification.

Appropriate referral: It was important to recognise that situations might be unpredictable hence; the researcher ensured that referral systems were in place to deal with any adverse reactions. This was to avoid harm of any kind, should any of the research participants suffered emotional or physical distress as a result of participating in the research process.

\section{Data analysis}

The author analysed data using six steps as mentioned by Creswell. According to Creswell (2014), his six steps data analysis approach are interrelated and do not necessarily follow in the order they are given. First, the researcher organised and prepared the data for analysis. Interviews were transcribed from the audio recording, sorted and arranged. Second, the data was read through thoroughly. By doing this, the researcher gets a general sense of the information and its overall meaning. This also helps the researcher to write down general ideas about the data. Third, the chunk of information was coded by writing a word that represents a category in the margin. Fourth, a description of the setting or people and categories or themes for analysis was given. This process enables the researcher to give detailed descriptions of the setting or the people involved as well as descriptions of the categories or themes for analysis. Fifth, the researcher presented the results of the analysis in the discussion of the findings. This was done in a narrative passage by presenting participants voices to convey the findings of the analysis. The author did this through a chronological presentation of events, a detailed discussion of several themes or a discussion of interconnecting themes. Finally, the researcher interpreted the results from the analysis. The aim was to answer the research questions. This was done with the idea that qualitative research data analysis is an ongoing process right from the time of the data collection to the conclusion of the research (Maree, 2007).

\section{Trustworthiness}

In a qualitative study trustworthiness refers to the manner of ensuring dependability or reliability of data collection instruments, the process followed in gathering the data, the quality of data gathered and their validity. The researcher ensured trustworthiness by making sure that all responses from participants were written down. Also, in the field work, whatever was heard, seen and observed was recorded. He used different techniques to ensure that the findings of the study are reliable. For example, the researcher used probing questions to help participants understand better. He also, asked 
the participants to repeat their answers so that only the right answers given are written down. In this way the respondents gave credible information which ensured the dependability or reliability of the study.

\section{Findings and Discussions}

The use of respondents' voice in research is always very important to validate the findings and it is for this reason that selections from the transcripts of interviews have been used to ensure that the women voices are heard since the research study concerns them. In this section, the findings are presented based on the themes that emerged from the data analysis. These included the following:

- Inadequate resources available to women.

- Inadequate skills development programmes provided to women.

- $\quad$ Skeptical economic benefit of ACET programmes to women.

\section{Inadequate Resources Available to Women}

The women stated that resources that enhanced teaching and learning at ACET centres in Lukisikisi were inadequate and therefore, could not provide the much-needed skills. Moreover, villages and rural communities are located very far away from the ACET centres. The physical conditions at the schools are also inadequate. These, therefore, affected the women negatively in their search for economic development. Despite the progress made in the educational development and access to education (adult education in particular) young people, women, in particular, have been unable to access the economy at the required measure (Mayer et al., 2011). With regard to the inadequate resources available to the women one respondent voiced her concern in this way:

The place where we study is not good for us. We don't have our own classrooms and the chairs and tables are too small for us. We are using the classroom for children. Most of us are sitting on the tables because our legs cannot fit under the desk. We do not come to school regularly because our villages are very far and we don't have money to come all the time.

These concerns were raised to show that the women do not have access to appropriate learning facilities at the centres which made learning and accessibility to ACET programmes very difficult. These inadequate resources have impacted negatively on the women. It has contributed to the lack of adequate skills amongst women, unemployment and the high rate of poverty. The literature affirmed that inaccessibility to ACET programmes was due to a lack of interest in the programmes because it failed to provide women with necessary skills for the labour market. According to Baatjes (2008), the programmes of ACET have failed in providing the much-needed 
skills for which it was intended. The author further asserted that ACET serves a politically under-represented clientele, lacks focus and cannot compete with the better funded formal education system. However, the formal education system has failed to teach the skills needed for economic development. It is for this that Apama and Andong (2008) criticised the formal school system for its inability to teach the skills, which relate to rural conditions of most people living in the rural areas of which women form the majority. Comparing the two systems of education it is declared that the formal system of education is selective, exclusive and discriminatory. On the other hand, Adult and Community Education and training take care of a wider domain and it is non-discriminatory in any society (Osuji, 2006). Moreover, ACET offers only low-level skills that do not qualify for the global market.

\section{Inadequate Skills Development Programmes Provided to Women}

The responses from the women reveal that they are not being trained or helped to acquire the necessary skills like sewing, baking etcetera to be able to run their own business and engage in community projects. This has led to their low economic development. The programmes are geared towards acquiring a low-level certificate at the end of their studies (Umalusi, 2008) which makes it very difficult for the women to get jobs. Having no jobs will lead to poverty and low economic development. The following are some of the views of the respondents concerning the programmes offered at the centres:

The centre is providing us with ACET certificate that we can use to find jobs in our community but, it is very difficult to find a job. We are not actually learning skills to do our own work or run our own business like dress-making, baking or being an electrician.

Another participant said;

We are having a subject Agriculture Science but, we are not doing any practical work that will help us acquire the skill better. We are only taught the theory aspect which makes us not to do very well on the farm. We also need computer skills that will help us well.

Yet another also said;

If we can have computer skills training, sewing and baking at our centre then it will help us to do better. We don't have these training here and this is what we need the most to help us develop ourselves economically.

These revelations by the respondents affirmed that the problem of inadequate skills development provided to women emanated from a lack of cooperation between the Departments of Education and Labour as well as the absence of a streamlined, collaborating bureaucracy within every department 
(University of Cape Town, 2007). According to Bischoff and Govender (2004) in their report, the national skills strategy was intended to revolutionise the skills development among women. However, they identified a lack of clear direction and a system that was open to corruption and abuse as factors impacting negatively on skills development in South Africa (Bischoff \& Govender, 2004). Furthermore, Freeman (2009) sustains that the skills revolution has never really taken hold in South Africa. The author is also critical of the programmes for carrying too much intellectual weight, seeing this as producing a barrier particularly for young unskilled people from economically and educationally impoverished households. In the same vain Kraak (2004) confirmed in the literature that skills development amongst women are desperately and urgently needed if the economy was to be competitive on the global market. Therefore, skills acquisition should be a vigorous process of moving people from being unskilled or semi-skilled to skilled, and from being unemployed to employed or self-employed. According to Vass (2009), there must be a drastic, complete change in the state of skills of the entire society or workplacebased skills development. This, therefore, indicated that the real needs of women which are the development of skills should be given priority in government policies and implementation. This will help lift the status of economic development of women in the lusikisiki district.

\section{Skeptical Economic Benefit of ACET Programmes to Women}

The economic development of women is dependent on the fact that the women are employed in the job market. However, this has not been the case. Data collected revealed that ACET programmes are designed to reward learners with certificates to use in the search for jobs after their studies (Umalusi, 2008). However, the certificate provided is of low quality and not relevant to the job market (Mayer et al., 2011). The women are not being trained with the necessary skills like sewing, baking, pottery etc. As indicated in the literature review above, there is a strong likelihood that most of the women will remain unemployed after their studies since they have to go look for jobs with very limited skills. The strong conviction that the women are supposed to have in finding jobs at the end of their studies is very skeptical. This was actually confirmed by the participants when they said in different responses below:

Most of us women learners who will graduate from ABET will look for our own jobs. Maybe we can get a job.

After my studies, I do hope to use my certificate to look for a job in the shops like Spar and Shoprite. 
I am hoping that I will get a job after my studies but there are no jobs. My friends are still sitting at home hoping that one day they will get a job.

The comments from the respondents show that most women from the ACET centres endeavour to build their lives on the programmes and see it as the only means of gaining employment and economically develop themselves. However, their hope of gaining employment is very faint due to the low-level training that they received. The literature revealed that there are concerns about the increase in unemployment numbers and insufficient skills to be absorbed in the current labour market. It is, therefore, worrying that there are still a significant number of young women who are unemployed and living in poverty (Turton et al., 2007). This worrying trend is supported by ILO study (2006) which also specified that unemployment is one of the grave challenges facing the youth globally, especially women.

\section{Conclusion}

The study explored the effect of Adult and Community Education and Training (ACET) on the economic development of women in Lusikisiki, South Africa. The findings were discussed based on emerging themes from the presentation. These themes were inadequate resources available to women, inadequate skills development programmes provided to women and skeptical economic benefit of ACET programmes to women. The Women were concerned about the inadequate facilities and a lack of resources which affected their learning and accessibility to ACET programmes. These inadequate resources contributed to a lack of economic development, inadequate skills amongst women, unemployment and the high rate of poverty. Women are not being trained with the necessary skills, for example, sewing, pottery and baking to be able to run their own business and engage in community projects. The programmes are geared toward acquiring a lowlevel certificate at the end of their studies which makes it very difficult for the women to get jobs. The economic development of the women is centered on ACET programmes. However, lack of appropriate skills made it difficult for women to be absolved in the labour market. Therefore, their strong conviction of gaining employment at the end of their studies is skeptical. There is a strong suggestion from the author that there is an urgent need for government intervention in reviewing ACET programmes for women, especially in the Lusikisiki district. This is because the study has revealed that the current programmes do not meet the needs of women involved in ACET programmes. Further, the women should be given a platform in which to air their views as to issues that concern them in community forums. 


\section{Recommendations}

Following the findings discussed above the study recommends that the programmes of Adult and Community Education and Training should be reviewed to meet the needs of women. Also, appropriate skills programmes should be developed to empower women for job opportunities in the country. This will help women engage in socio-economic activities of their communities and country nationally. Furthermore, governmental authorities should provide adequate educational resources to enhance women development. Finally, women should be given a platform to share their views on issues that concern them. In this case, the kind of skills training that they need the most to enable them to gain employment for better living conditions.

\section{Limitations of the Study}

The researcher used this section to comment on the limitations of the study. As the study was conducted with 35 participants using qualitative interviews in the Lusikisiki district of South Africa, the experiences of the women cannot be generalised. This is because only a small number of participants were involved in the study. The situation of the women might differ in other rural communities. Against these limitations, therefore, the conclusions of the study should be interpreted with the limitations mentioned above in view.

\section{References:}

1. Adelore, O.O. \& Olomukoro, C.O. 2015. Influence of Literacy Education Programmes on Socio-economic Empowerment of Women in Edo and Delta States, Nigeria. US-China Education Review, 5(5), pp.315-324.

2. Akintayo, M.O. \& Oghenekohwo, J.E. (2004). Developing adult education and community development: New paradigms. Ibadan: Educational Research and Study Group.

3. Apama S.I. \& Andong H.A. (2008). Vocational training and women empowerment opportunities in central senatorial zone, Cross River State, Nigeria. Adult Education in Nigeria. NNCAE. Ibadan vol. 6: pp.288-301.

4. ASPBAE (2012). The power of literacy: women's journeys in India, Indonesia, Philippines and Papua New Guinea, Manila: ASPBAE

5. Baatjes, I. G. (2008). Adult Basic Education Training. In Kraak, Andre and Press, Karen (Eds.) Human Resources Development Review. Education, Employment and Skills in South Africa. Cape Town: HSRC Press, p. 206 - 227.

6. Becker, G. S. (1964). Human capital: A theoretical and empirical 
analysis with special reference to education. Chicago, I.L.: The University of Chicago Press.

7. Berg, B., L. (2004). Qualitative research methods: for the Social Sciences. Boston, Califonia.

8. Bisschoff, T. and Govender, M. C. (2004). A management framework for training providers to improve skills development in the workplace. South African Journal of Education, No. 24, p. 70-79.

9. Chaska, N.L. (2008). The nursing profession: Tomorrow and Beyond. California: Sage.

10. Creswell, J.W., \& Plano Clark, V.L. (2011). Designing and conducting mix methods research ( $2^{\text {nd }}$ ed.). Los Angeles, CA: Sage

11. Creswell, J.W., 2014, Research design: Qualitative, quantitative and mixed methods approaches, 4th edn., Sage, Thousand Oaks.

12. Federal Government of Nigeria (FGN), (2004). National policy on education. 4th Edition Lagos, Nigeria NERCD.

13. Freeman, J. (2009). Skills revolution gets a shot in the arm. 30.06.09. http://www.skillsportal.co.za/skills-development/090630-QCTOskillsdevelopment- fet-learning.htm, 03.09.09.

14. HSRC (Human Sciences Research Council), (2002). Youth and the demographic dividend. Roundtable Learning Series, HSRC, Pretoria, quoting David Bloom et al., 2002, the demographic dividend: A new perspective on the economic consequences of population change. Population Matters, Rand Afrikaans University, Johannesburg.

15. IFAD-UNESCO (2014) Learning knowledge and skills for agriculture to improve rural livelihoods [Synthesis Report written by A. Robinson-Pant], Paris: UNESCO Available at: http://www.unesco.org/new/en/education/themes/education-buildingblocks/technical-vocational-education-and-training-tvet/learningknowledge-and-skills-for-agriculture-and-rural-livelihoods/

16. Igbuzor O. (2006), State of education in Nigeria. A key note address delivered at a round table organized by Civil Society Action Coalition on Education for all on 3rd July, 2006.

17. INSTITUTO DE PESQUISA ECONÔMICA APLICADA (2010) (IPEA). Dimensão, evolução e projeção da pobrezaporregiões e estados no Brasil. In: Comunicados da Presidência, n. 58, Julho de (2010).

18. International Labour Office (2006) Global Employment Trends for Youth. Geneva, Switzerland.

19. Kairies, J., 2013. Literacy Programmes with a Focus on Women to Reduce Gender Disparities: Case Studies from UNESCO Effective Literacy and Numeracy Practices Database (LitBase). Form http://www. unesco. org/uil/litbase/. UNESCO Institute for Lifelong 


\section{Learning.}

20. Kraak, A. (2004). An overview of South African human resources development. Cape Town: HSRC Press.

21. Leibbrandt, M., J. Levinsohn, and McCrary, J. (2010). Incomes in South Africa after the fall of apartheid. Journal of Globalization and Development 1(1)

22. Lockhead, M. E., Jamison, D. T., and Lau, L. J. (1980). Farmer education and form proficiency: A survey in World Bank staff (Working Paper No. 402). Washington, D. C.: World Bank.

23. Maree, K. 2007. First steps in research, printed and bound by pearl print, Ouster land Street, Dal Josafat, Paarl, South Africa.

24. Mattei (2015). Industrialização e substituição de importações no Brasil e na Argentina: umaanálisehistóricacomparada. Revista de Economia.

25. Mauch, W. (2014). Education or Sustainable Development in Adult Education and Lifelong Learning, Background paper for the final report 2014, 'Celebrating a United Nations Literacy and Education for Sustainable Development and Women's Empowerment.

26. May, J. \& Govender, J., 1998. Poverty and inequality in South Africa. Indicator South Africa, 15, pp.53-58.

27. Mayer, M.J., Gordhan, S., Manxeba, R., Hughes, C., Foley, P., Maroc, C., Lolwana, P. and Nell, M., 2011. Towards a youth employment strategy for South Africa. Development Planning Division working paper series, (28).

28. Millennium development goals (2013): Country report 2013. Pretoria: Stats SA.

29. National Population Commission (NPC) (2006). National population commission of Nigeria, population figures. From http://www.nigeriavillagesquare.com/articles/nvs/npc-releases-2006population-figures-14.html.

30. Nwabuke L.O. (2008). New proposal for establishing Adult and nonformal education system in Nigeria. Journal of the Nigeria Council for Adult Education.

31. Okpoko J.M. (2002). Empowering women for community development through Non-formal education (NFE) programme. Journal of Adult Education and Development. 1(1).

32. Olomukoro, C.O. (2012). Influence of literacy education programmes on socio-economic and psychological empowerment of women in Edo and Delta states, Nigeria (Unpublished PhD dissertation, Faculty of Education, University of Ibadan).

33. Osuji S.N. (2006). Education for fullness: The role of adult education in Nigeria in the 21st Century. Journal of Social Science 12 (1) pp. 
49-54.

34. POCHMANN, M. Brasil, o país dos desiguais. In: Lê Monde Diplomatique, ano 1, n.3, outubro de (2007).

35. Presidency RSA, (2009). National Youth Policy 2009-2014. Presidency, Pretoria.

36. Reynolds, L. M., and Weagley, R. O. (2003). Academic persistence in higher education. Consumer Interests Annual, 49, 1-8.

37. Robinson-Pant, A. (2004) 'The illiterate woman': changing approaches to researching women's literacy' in Robinson-Pant, A. (ed) Women, Literacy and Development: Alternative Perspectives, London: Routledge

38. Statistics South Africa, General Household Survey (2012), DBE own calculations.

39. Tachibanaki, T. (1994). The international encyclopedia of education. Oxford, U.K.: Pergamon Press.

40. Tang, Q. (2005) UNESCO's New Literacy Initiative for the Excluded (LIFE) in Commonwealth of Learning, Literacy and Livelihoods: Learning for life in a changing world, Vancouver: COL, pp $21-26$

41. TAVARES SOARES, M.A. SalárioMínimo e o paradoxo da redução da desigualdade no Brasil. In: RevistaOikos, v.10, n.2, (2011).

42. Tilley, S.A., Killins, J. \& Oosten D.V. (2005). Connections and Tensions between University and School Districts: Research Review Boards and School-Based Research. The Alberta Journal of Educational Research, 51(3)277-292.

43. Turton, A.R., Hattingh, J.H., Maree, G.A., Roux, D.J., Claassen, M. and Strydom, W.F. eds., 2007. Governance as a trialogue: Government-Society-Science in transition. Springer Science \& Business Media.

44. UIL (2009). Global Report on Adult Education and Learning, Hamburg: UIL

45. UIL (2013) Literacy programmes with a focus on women to reduce gender disparities. Case studies from UNESCO Effective Literacy and Numeracy Practices Database (LitBase), Hamburg: UNESCO Institute for Lifelong Learning http://www.unesco.org/uil/litbase/

46. Umalusi (2008). The state of national curricula for Adult Basic Education \& Training: Letting a thousand flowers bloom or a disaster of decentralization? Pretoria: Umalusi

47. UN (2012) Resilient People Resilient Planet: A future worth choosing, the report of the UN Secretary-General's High-Level Panel on Global Sustainability, January 2012

48. UNEP - United Nations Environment Programme, (2011). Towards a green economy: pathways to sustainable development and poverty 
eradication. From http://[www.unep.org/greeneconomy (accessed 2012 May 25)

49. UNEP, FI. "Fiduciary responsibility: Legal and practical aspects of integrating environmental, social and governance issues into institutional investment." UNEP FI: Geneva (2009).

50. UNESCO (2013) Proposal for a global action programme on Education for Sustainable Development as follow-up to the UN DESD after 2014, General Conference, 37th. Session, 4th. November 2013

51. UNESCO, E., 2007. Global Monitoring Report (2008): Education for All by 2015. Will We Make It. United Nations Education, Science and Cultural Organization, Paris

52. UNESCO-INRULED (2012) Education and training for rural transformation: skills, jobs, food and green future to combat poverty (Beijing)

53. University of California, (2014). The Regents. (UK) Government White Paper on International Development 2000. Eliminating World Poverty: Making Globalisation Work for the Poor. London: HMSO.

54. University of Cape Town (2007). Skills Shortages in South Africa: Key Issues. Cape Town.

55. Vass, J. (2009). Risks and Opportunities in shifting skills development from labour to education. In: HSRC - Review of Education, Skills Development and Innovation. November 2009, p. 4 -8 .

56. Welman, C., Kruger, F., and Mitchell, B. (2005). Research Methodology. Oxford: Oxford University Press. 